\title{
JUEGOS DE ROL Y ROLES DE GÉNERO
}

Resumen: El artículo analiza la evolución de los juegos de rol desde la perspectiva de los estudios de género. Los autores analizan la evolución de los juegos de rol y la incorporación progresiva de las mujeres a esta forma de ocio.

Palabras clave: juegos de rol, género; estudios de mujeres 


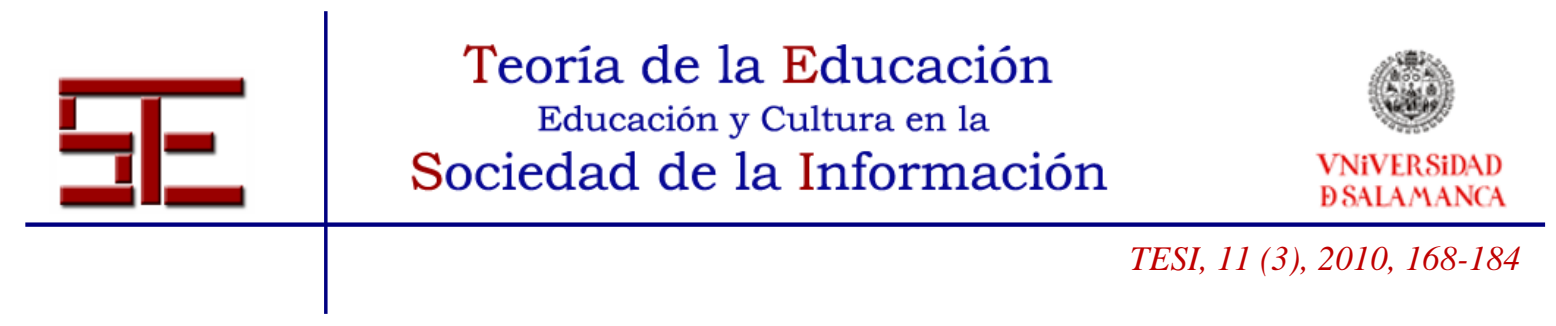

\section{ROLE PLAYING AND GENDER ROLES}

Abstract: This paper focuses on the role playing games evolution from the Gender perspective. The authors analyze the evolution of the role playing games and the progressive incorporation of women to this form of games.

Key words: role playing games, gender, women studies

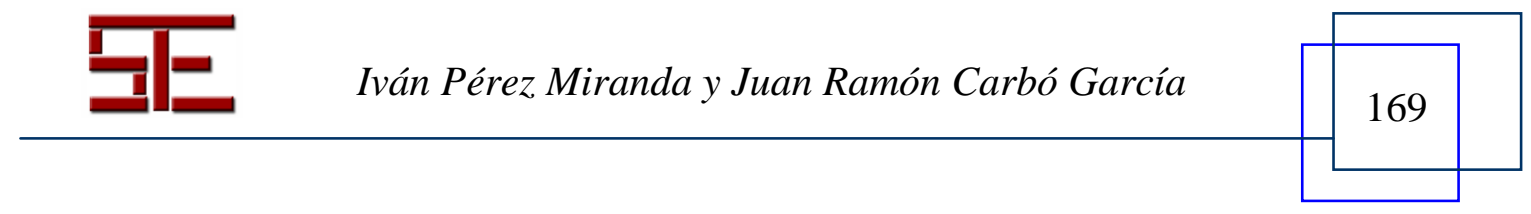




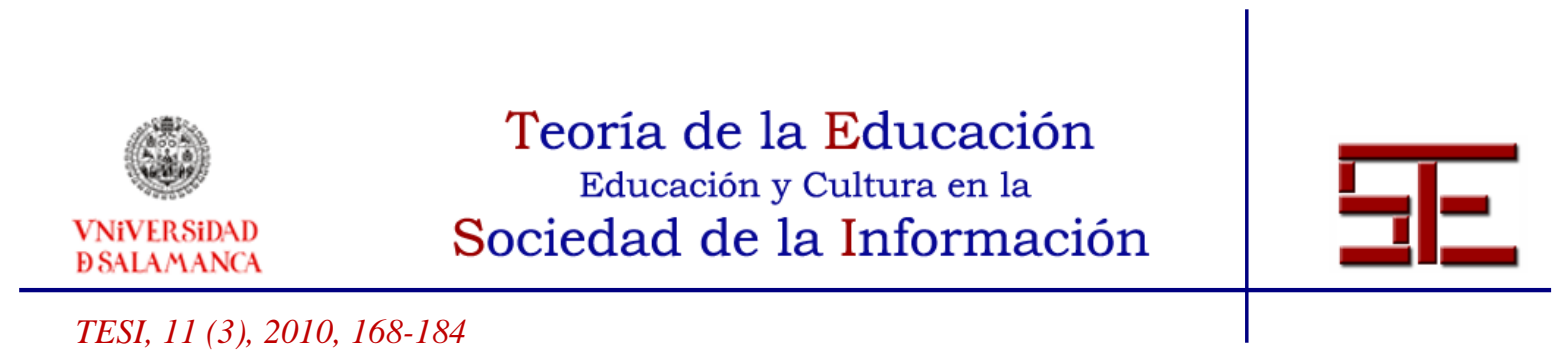

\title{
JUEGOS DE ROL Y ROLES DE GÉNERO
}

Fecha de recepción: 26/06/2010; fecha de aceptación: 21/09/2010; fecha de publicación: 30/11/2010

\author{
Iván Pérez Miranda \\ ivan@usal.es \\ Universidad de Salamanca \\ Juan Ramón Carbó García \\ siren_de_sorren@hotmail.com \\ Academia de Rumanía en Roma - Universidad Complutense de Madrid
}

Ya en agosto de 2003 Merja Leppälahti (Leppälahti, 2003) presentó en la Universidad de Lund, en Suecia, una ponencia en la que acercaba los juegos de rol a los estudios feministas. Pretendemos en este caso acercar los estudios de género al análisis de los juegos de rol.

La prensa ha jugado un papel importante tanto en la polémica suscitada en torno a los juegos de rol, como en la relativa a lo apropiado o no del uso del término 'género' que ha tendido a generalizarse, tanto en los medios académicos como a nivel popular.

Muchos autores consideran más adecuado el empleo del término 'sexo', así por ejemplo Juan Fernández consideraba que:

\begin{abstract}
muchas investigaciones actuales parecen seguir al pie de la letra la regla de sustituir la palabra sexo por la de género allí donde aquella pueda aparecer, sin importar lo más mínimo el contenido al que se pueda estar haciendo referencia (el autor ha sido, en alguna ocasión, víctima forzada de esta regla, en alguno de sus trabajos). De esta forma, lo "políticamente correcto" extiende sus dominios, ya que el vocablo sexo suena incomparablemente peor, para cualquier oído fino y elegante, que el de género. (Fernández, 1988, p. 148)
\end{abstract}

En una línea similar a Juan Fernández, expone $M^{\mathrm{a}}$ Encarna Sanahuja (Sanahuja Yll, 2005, 89), desde el feminismo de la diferencia, que "el género se ha convertido en políticamente correcto y, en la gran mayoría de las ocasiones, lo políticamente correcto oculta lo fundamental".

Sin negar la parte de verdad que encierran estas opiniones, no creemos que el hecho de que la palabra 'sexo' esté considerada por muchos como tabú sea motivo suficiente para no emplearla cuando sea conveniente, al contrario, se trata de una palabra que se puede

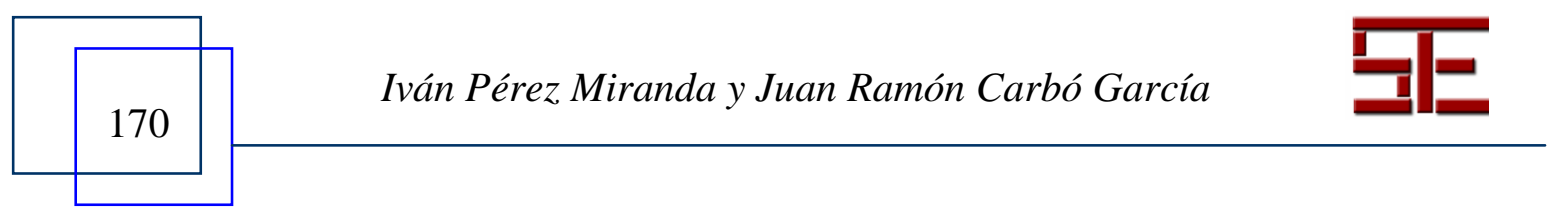




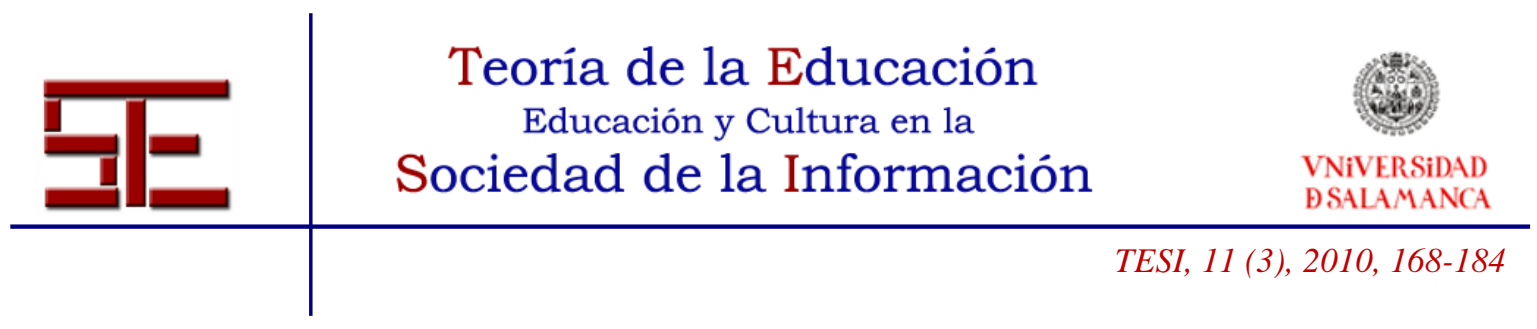

emplear en castellano con toda propiedad. De igual modo, el hecho de que la palabra 'género' sea utilizada por algunos por el hecho de ser "políticamente correcta", no quiere decir que no pueda utilizarse con rigor y precisión.

Como veremos, 'sexo' y 'género' no son sinónimos, a pesar de la tendencia que hay de usar estos conceptos indistintamente, del mismo modo que se tiende a pensar erróneamente que 'género' alude principalmente a las mujeres.

Es bien sabido que la palabra 'género' es utilizada como traducción del anglicismo 'gender'. El que el uso, en inglés, de la palabra 'gender' es totalmente correcto es algo indiscutible; en todo caso recurrir al diccionario nos sacaría de dudas inmediatamente. Como expone Pilar García Mouton (García Mouton, 2002, 134): "El English Lenguaje Dictionary de Collins (1987), por ejemplo, da como primera acepción de gender: "In formal English, gender is the fact of being male or female; used of people and animals. EG ... differences of temperament, race or gender ... someone of the male gender"”.

En castellano (así como en otras lenguas romances), por el contrario, levanta cierta polémica, aunque es cierto que cada vez tiende a generalizarse, tanto en los medios académicos como a nivel popular, debido al uso, o al abuso, que de la palabra hacen (ya sea correcta o incorrectamente) los medios de comunicación.

Hay quien ha visto, y entre ellos eminentes filósofos, en la generalización del empleo de esta palabra un acto de sumisión de nuestro lenguaje al poder del inglés, o más concretamente, de sumisión al inglés utilizado en los Estados Unidos de Norteamérica, y a la O.T.A.N.

No puede negarse que al término 'género' se le ha ido dando cada vez una mayor importancia política desde la Conferencia de Pekín realizada en 1995 bajo la égida de la Organización de las Naciones Unidas, en la que se sustituyó la expresión "derechos de la mujer" por la de género (Fraise, 2003, 43).

Por supuesto hubo quien, dentro del feminismo, respondió enseguida a dichas críticas. Así, a modo de ejemplo:

Alicia Puleo García, directora de la Cátedra de Estudios de Género de la Universidad de Valladolid, discrepa, bajo el titulillo Género, en "Cartas al director" (El País, 11 de marzo de 2002) de las opiniones expuestas por Lázaro Carreter en el mismo diario el día 3 de marzo [...]:

En su artículo del 3 de marzo, el señor Lázaro Carreter sostiene que quienes han aceptado traducir "gender" por "género" para referirse a la diferencia de los sexos entre los humanos "macarronizan" y ejercen violencia contra el idioma.

En su lugar propone las palabras "naturaleza" y "sexo", demostrando así un desconocimiento total del tema, ya que, en las últimas décadas, el concepto de "gender" o "género" ha sido acuñado y desarrollado como teoría por las ciencias sociales justamente en contraposición a las categorías de "sexo" y de "naturaleza".

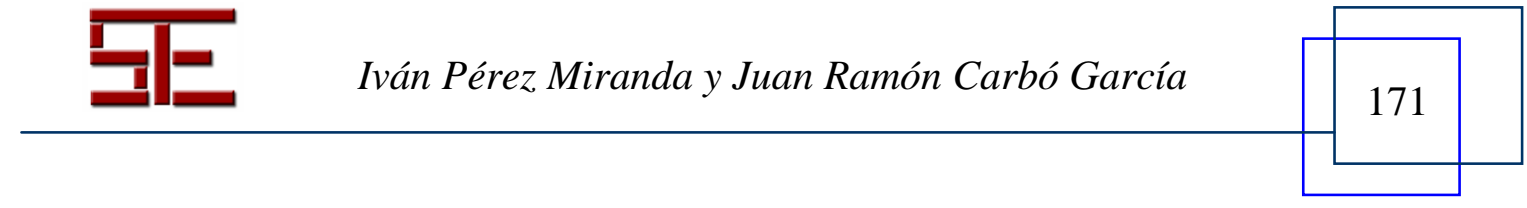




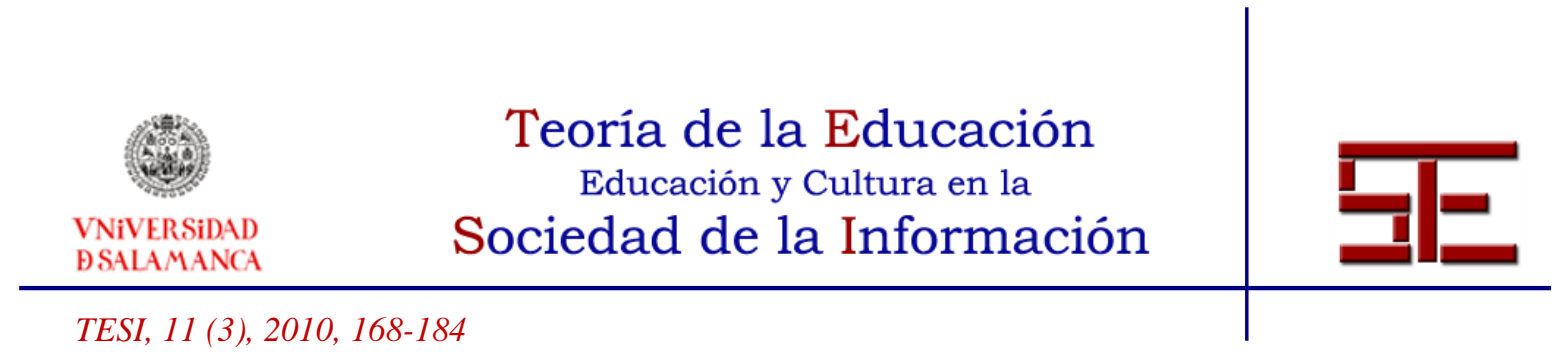

"Género" alude a la construcción sociocultural, histórica, que los grupos humanos elaboran sobre
las diferencias anatómicas naturales de sexo y no, como piensa nuestro académico, "condición,
índole o naturaleza" con que hombres y mujeres nacen (Sau, 2000, 134).

Género hace pues referencia a los roles, responsabilidades y oportunidades asignados en función del sexo (hombres y mujeres), y a las relaciones socioculturales que se establecen entre ellos. Podemos decir así que el género es una construcción simbólica, una realidad psicosocial, y no física, aunque evidentemente esté en gran parte motivada por el dimorfismo sexual (mujer/varón). No debemos confundir los conceptos de género, sexo y sexualidad pues, aunque exista relación entre estos tres conceptos, cada uno de ellos alude a una realidad determinada.

Una mujer nace mujer, y un varón nace varón, eso es lo que supone 'sexo', pero además existen unos imperativos, no ya biológicos, sino culturales, que imponen, tanto a la mujer como al hombre, por el mero hecho de serlo, el deber de aprender a comportarse como socialmente se considera que es correcto que deben hacerlo. Se impone pues desde la sociedad el rol, la división del trabajo en la economía y en el hogar, así como los desequilibrios de poder. Y sólo dándonos cuenta de esta realidad podremos volver a observarla, repensarla y crear nuevos roles de género que estén basados más en el respeto, la coeducación y la equidad que los actuales.

En este artículo pretendemos hacer un acercamiento acerca de la relación existente entre los roles de género y los juegos de rol.

Es de sobra conocido que los juegos de rol fueron muy criticados y desprestigiados por la prensa, debido a una ignorancia del tema inconsciente o deliberada, especialmente desde que Javier Rosado y Félix Martínez asesinasen a sangre fría a Carlos Moreno el 30 de abril de 1994 en el llamado entonces "crimen del rol".

Rafael Torres escribía en el diario El Mundo (9 de junio de 1994) el artículo "Una necrosis similar" en el que defendía que:

\begin{abstract}
Los videojuegos, y seguramente también ciertos dibujos animados de la televisión, producen hemitrofia cerebral a medio plazo, pero los juegos de rol provocan necrosis fulminantes en los tejidos de la cabeza y del corazón. Ideados para imbéciles profundos, o bien para volver profundamente imbécil al que todavía no lo es, no se explica muy bien qué hace el decanato de la Facultad de Ciencias, donde cursa no sabemos qué estudios el psicópata Javier Rosado, subvencionando la compra de esos juegos de tan ínfima catadura cívica y moral.
\end{abstract}

El impacto mediático de los ataques a los juegos de rol ha provocado incluso que se hiciesen películas en nuestro país: Nadie conoce a nadie, de Mateo Gil, El Corazón del

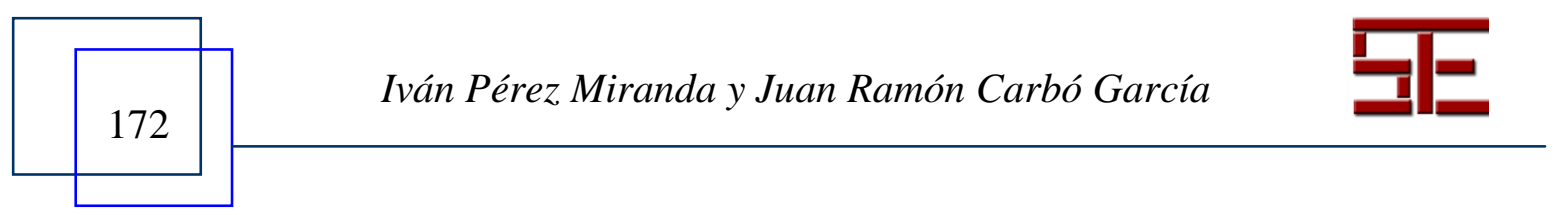




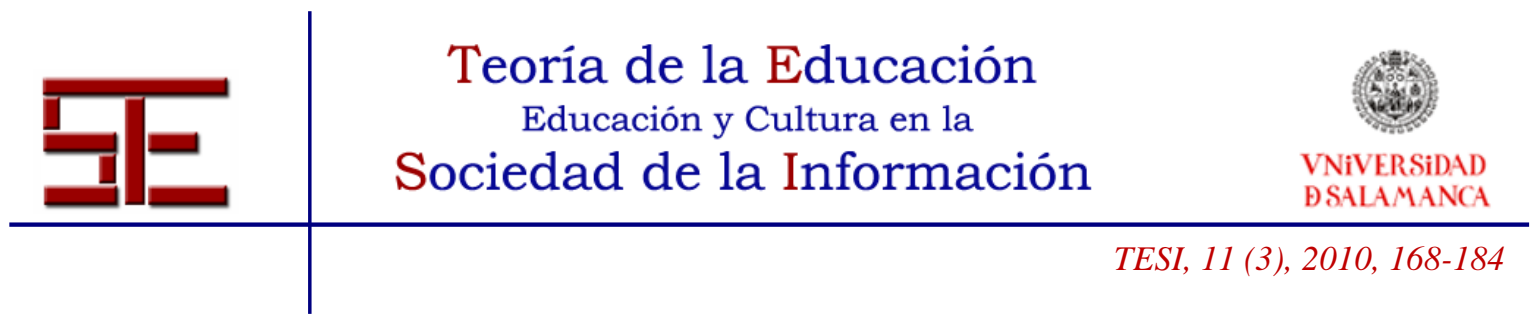

guerrero, de Daniel Monzón, ambas de 1999, o más recientemente La Caverna, de Eduard Cortés, 2000, y Jugar a Matar, de Isidro Ortiz, 2003 (Sánchez, D, 2003, 98126), e incluso libros de autoayuda como el escrito por los hermanos San Sebastián Cabasés (San Sebastián Cabasés, I. y San Sebastian Cabasés, J., 2004) con el sugerente y alarmista título ¿A qué juegan nuestros hijos?: botellón, rol, videojuegos y otros peligros de la infancia y la adolescencia en el que desde el completo desconocimiento de los temas tratados se arremete contra los juegos de rol, los videojuegos e Internet, considerándolos como un peligro en el mismo nivel cultural que el botellón, que supuestamente consiste en hacer apuestas sobre quién es capaz de ingerir mayor cantidad de alcohol en menos tiempo. Los videojuegos son considerados como machistas, aunque teniendo en cuenta que Isabel San Sebastián Cabasés, quien trabajó en El Mundo y en Antena 3, la cadena de televisión más crítica con los juegos de rol, también considera machista a la píldora anticonceptiva, tal y como defendió en el diario El Mundo el 14-5-2009 (<http://www.elmundo.es/opinion/columnas/isabel-sansebastian/2009/05/14836885.html >), su opinión en este ámbito, desde la perspectiva feminista, es altamente cuestionable, ya que desde el feminismo no son pocos quienes ven en la píldora anticonceptiva una herramienta para la igualdad.

En España, también los aficionados a los juegos de rol han hecho estudios sobre el tema: es el caso del trabajo de investigación Juegos de Rol: Mito y Realidad (Sánchez, D., 2007), del libro Creer lo Increíble (Tizón R, 2007) e incluso se ha realizado una tesis doctoral: El sector editorial de los juegos de Rol: análisis del editor, el lector y el traductor, de Héctor Sevillano Pareja, defendida el 10-10-2008 en la Universidad de Salamanca, con la máxima calificación.

En este artículo solamente pretendemos incluir la perspectiva de género en el análisis de los juegos de rol.

Los juegos de rol en su origen constituían una afición claramente masculina, en el que las mujeres apenas participaban. Sin embargo, con el paso del tiempo, las mujeres se han ido, poco a poco, incorporando a este tipo de entretenimiento.

En un juego de rol es necesario diferenciar entre los jugadores (entre los que se encuentra el director de juego) y los personajes que éstos interpretan. En ambos ámbitos podemos ver, desde la perspectiva de género, una evolución en los juegos de rol.

Como decimos, en los comienzos el rol era una actividad masculina; los juegos estaban escritos por varones, para varones, y las chicas ocupaban un papel escaso como jugadoras, y casi nulo como directoras de juego.

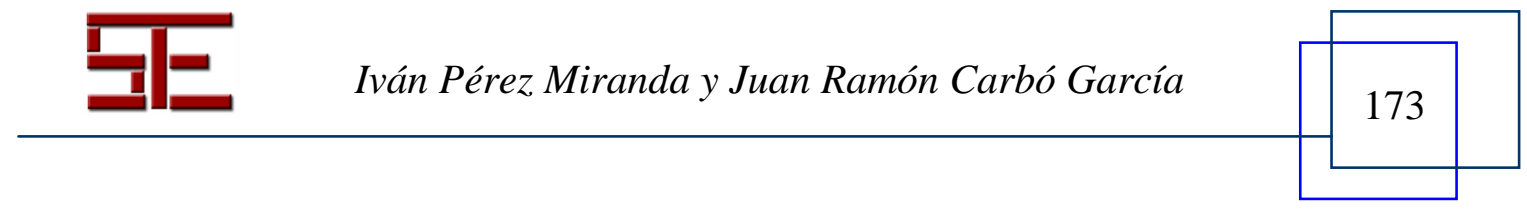




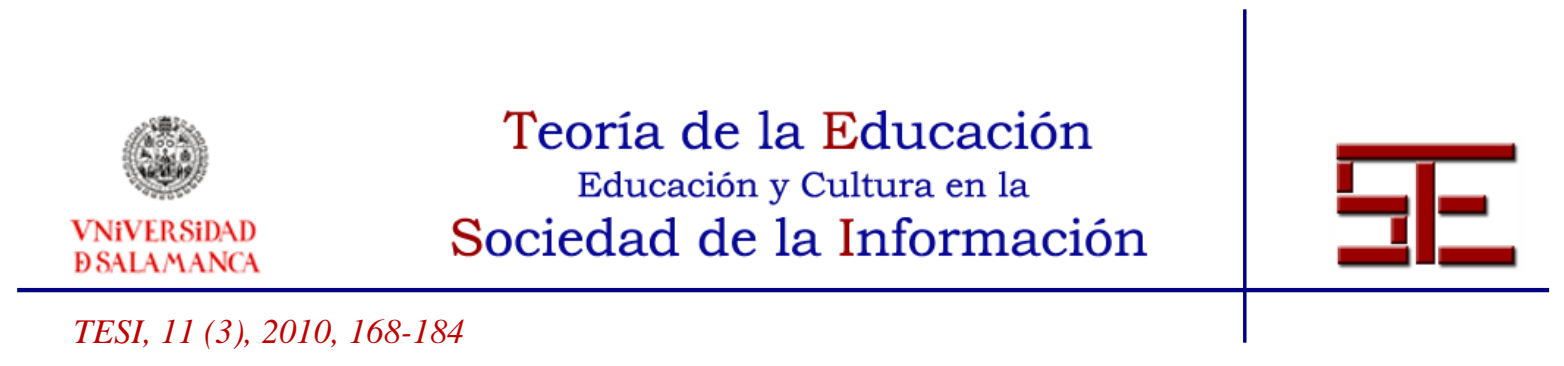

El término que se utilizaba para referirse al Narrador o Director de Juego era el utilizado en el juego Dungeons \& Dragons: Dungeon Master, un término masculinizado, del que es complicado hacer el femenino. En español es frecuente que los jugadores hablen de "las masters", pero en inglés el equivalente femenino de Dungeon Master sería Dungeon Mistress, término que tiene connotaciones un tanto machistas: por un lado, mistress es el término que se emplea en inglés para referirse a las amantes de hombres casados, y por otro dungeon mistress tiene claras connotaciones sadomasoquistas. Juegos más actuales utilizan términos como Director de Juego o Narrador (en inglés Storyteller), por lo que se puede hablar con facilidad de Directoras de Juego o Narradoras. Posiblemente sean términos que describan mejor el papel del Director de Juego, que no se limita simplemente a interpretar los personajes monstruosos que pueblan los calabozos de los mundos de fantasía, sino crear y dirigir una historia en la cual los jugadores y jugadoras participan activamente con sus personajes.

Afortunadamente, desde nuestro punto de vista, en la actualidad ya nadie se sorprende, como pasaría hace unos años, por ver a una chica dirigiendo una partida de rol, ya sea en mesa o en vivo.

En los orígenes de los juegos de rol, como decimos, éstos estaban destinados a un público masculino y joven. Se narraban aventuras llenas de acción, de combates, de monstruos, búsquedas de tesoros, batallas, exploración de territorios salvajes... Estas aventuras solían ser desarrolladas por un grupo de personajes masculinos. Interpretar un personaje femenino era una rareza. Algunos juegos hacían que los personajes femeninos y los masculinos tuviesen características diferentes. Así por ejemplo, Aquelarre, publicado por Ricard Ibáñez en la editorial Joc (1990), otorgaba un modificador positivo a la apariencia de las mujeres. Es decir, las protagonistas femeninas eran más hermosas que los protagonistas varones, quizás como una forma de compensar las dificultades que tendría el personaje en el juego, una opción que no acababa de convencer a todos los jugadores, ni especialmente a las jugadoras.

Los personajes femeninos aparecerían como secundarios, a veces incluso sin nombre, como la dama en apuros o la princesa que debía ser rescatada. Esto se ve claramente en los manuales de juego, en los que la inmensa mayoría de las ilustraciones correspondían a personajes masculinos. Por ejemplo, en El Señor de los Anillos (1984) de Joc Internacional, todas las razas y profesiones que se podían escoger para los personajes venían acompañadas de un dibujo de un personaje masculino. Actualmente la gran

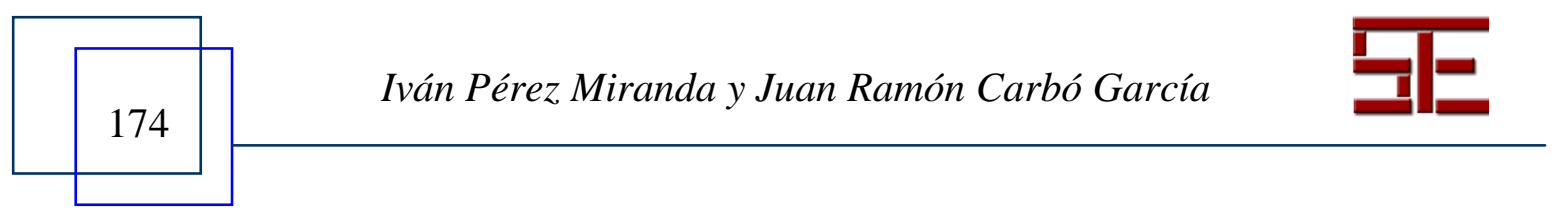




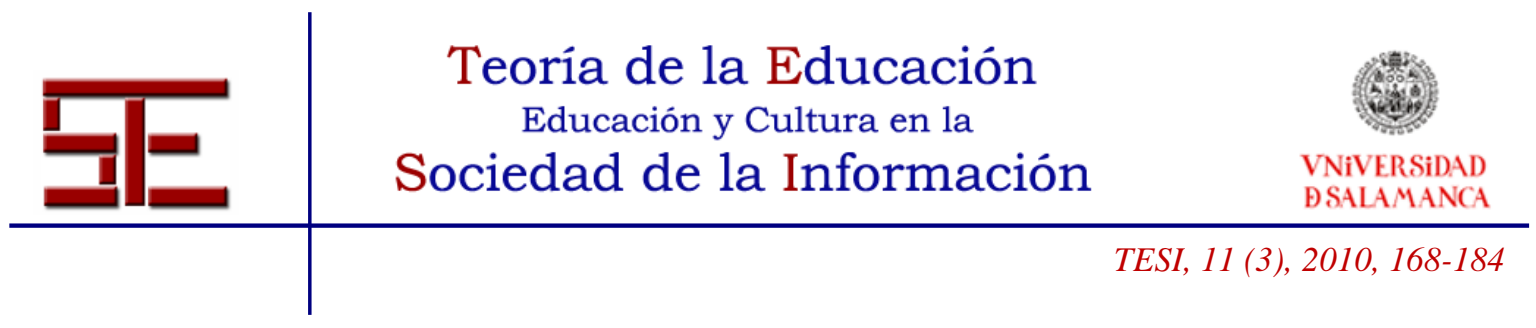

mayoría de los manuales incorporan un número equitativo de ilustraciones de personajes femeninos y masculinos.

Del mismo modo que las ilustraciones de los juegos de rol estaban destinadas principalmente a consumidores varones también lo estaban las de algunos tebeos, novelas, películas o videojuegos de fantasía de la época.

En las ilustraciones de fantasía, muchas veces portadas de novelas, videojuegos o discos de música, aparecen con frecuencia mujeres voluptuosas, desnudas o semidesnudas, "protegidas" por una armadura-bikini de metal o cuero tachonado.

Es comprensible que este tipo de imágenes atrajesen más a los jóvenes chicos que empezaron a jugar a los juegos de rol que a las chicas. De este modo, durante los años 80 , e incluso en los 90, ver a una chica jugando a rol era una auténtica rareza. En un artículo del año 1993 la revista Líder (n ${ }^{\circ} 38$ ), una revista especializada en juegos de rol, se exponía un catálogo de "especies" de jugadores de rol; la última categoría era para las chicas, más conocidas como: "Las novias". En él se decía lo siguiente:

\footnotetext{
La novia

Todo el mundo lo sabe: muy pocas chicas juegan al rol (ojalá hubiera más). Lo cual da un obvio resultado: pocas personas tienen novias jugadoras de rol.

Lo cual, a su vez, da otro obvio resultado: los jugadores de rol se afanarán por introducir a sus novias en el mundo que a ellos tanto les apasiona. Yo personalmente, creo que es más fácil que un hobbit armado con un mortífero palillo acabe con la vida de un dragón de un certero golpe, que una novia se enganche al mundillo que tan ilusionadamente le ofrece su cariñín (no soy sexista, simplemente constato un hecho comprobado).

Esto suele deberse a que tras horas de discusiones y fallidas intentonas, la chica acepta a regañadientes acudir con los amigotes de su media naranja a un lúgubre sótano para (a su entender) sentarse a una mesa toda la tarde y no hacer nada, y una vez en la partida se siente tan fuera de lugar como Sharon Stone veraneando en Valdemorillos de Arriba.

Lo que siempre me he preguntado es ¿Cómo sería jugar una partida de Paranoia con tu novia?, ¿te escupiría a la cara al terminar o se estaría lavando el pelo cada vez que la llamases durante los próximos treinta años? Todo es cuestión de comprobarlo. La frase favorita de esta especie es: "Me aburro, vámonos".
}

Andando el tiempo, los juegos de rol han ido evolucionando, dejando de ser una mera exploración de calabozos para dar mayor importancia a la interpretación de personajes cada vez más complejos que se relacionaban entre ellos de múltiples maneras. De este modo, los personajes femeninos ganaron cada vez mayor importancia, lo que acercó más al público femenino a este tipo de juegos.

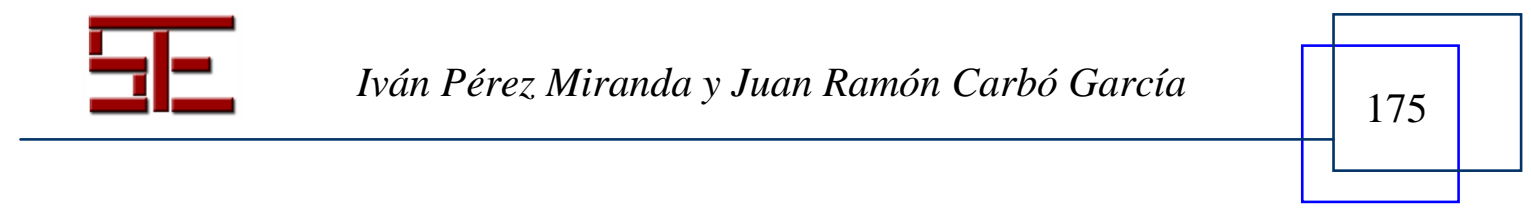




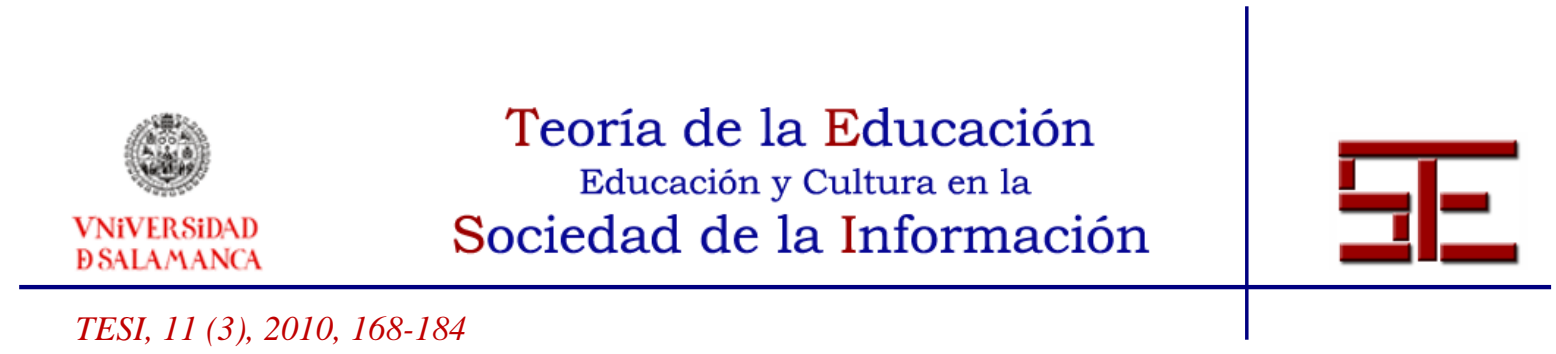

Si en un principio era corriente que las jugadoras de rol acudiesen a las partidas por ser novias o amigas de algún jugador, en la actualidad acuden por sí mismas y participan de una forma activa. La "desdemonización" de los juegos de rol en los últimos años y su difusión por canales como Internet han contribuido de manera considerable a ello, junto a la aparición de un tipo de juegos de rol donde se prima la interpretación sobre la acción. No queremos decir con esto que no haya jugadoras que prefieran interpretar a personajes sencillos cuya única finalidad en la vida sea explorar calabozos y vencer a cientos de monstruos en combate, con el objetivo de mejorar sus habilidades y sus riquezas, sino que la posibilidad de interpretar personajes más complejos y participar en tramas más enrevesadas atrae a un público diferente al de los primeros juegos de rol.

También la popularización de los juegos de rol en vivo ha atraído de manera considerable a jugadoras. El porcentaje de jugadoras en los juegos de rol en vivo es mayor que el de los juegos de mesa. Ello puede ser debido a la mayor carga interpretativa que suelen tener los juegos de rol en vivo, y a la atracción que ejerce la posibilidad de caracterizarse pues, en líneas generales, el sector femenino es más dado a los disfraces y a la caracterización que los chicos.

En marzo de 2005, la revista electrónica Nosolorol, dedicó su número 22 a las "mujeres", una iniciativa, desde nuestro punto de vista, muy positiva. Interés especial tiene el editorial, escrito por un varón, según el cual:

\begin{abstract}
Mujeres y roleros son conjuntos algo disjuntos. Nuestras lectoras pueden, si quieren, pensar que esto no es más que otro tópico de los tan extendidos en el mundillo, (...). Pero no, no se trata de otro estereotipo más y si no, ahí están los datos: las féminas son un bien escaso (y a menudo precioso) en jornadas, tiendas, partidas y prácticamente cualquier evento friki. Basta que una muchacha (o un troll oculto bajo un nick femenino) pregunte en una lista para que no solo reciba una cantidad interminable de respuestas, sino para que, además, se monte un flame. Lo vemos casi todos los días. Y mientras yo esperando indefinidamente a que alguien se digne a decirme si tal o cual suplemento merece o no la pena. Y es que tiran más dos tetas... O no. A lo mejor lo que pasa no es que los roleros sean unos salidos hormonados que se pasan el día imaginándose turgentes muchachas con minúsculos bikinis de cuero tachonado. Aunque bueno, viendo como se disparan las visitas de nuestros artículos cuando deslizamos como foto del mismo a una muchacha de buen año no sé muy bien que pensar...
\end{abstract}

Pero no importa, como sea, hay dos cosas muy claras: las mujeres frikis son escasas y los varones frikis corremos a protegerlas y mimarlas (y contemplarlas y babearlas...) y qué menos que dedicar a las mujeres, frikis y no frikis, un especial de NOSOLOROL. Al fin y al cabo ellas nos gustan (casi) tanto como el rol, los comics y el resto de nuestras aficiones, ¿no?

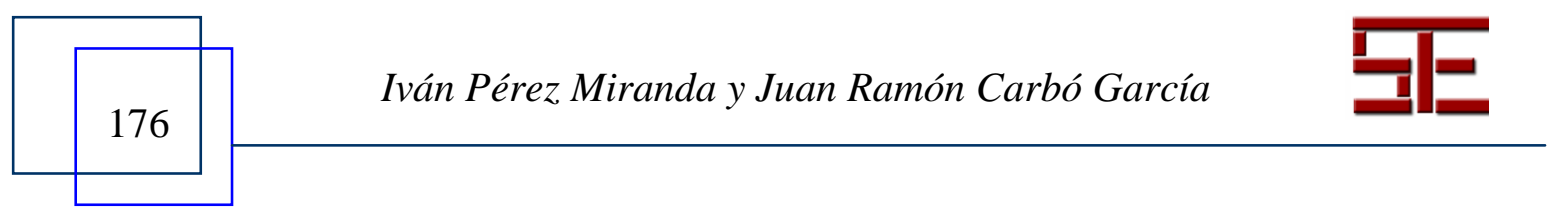




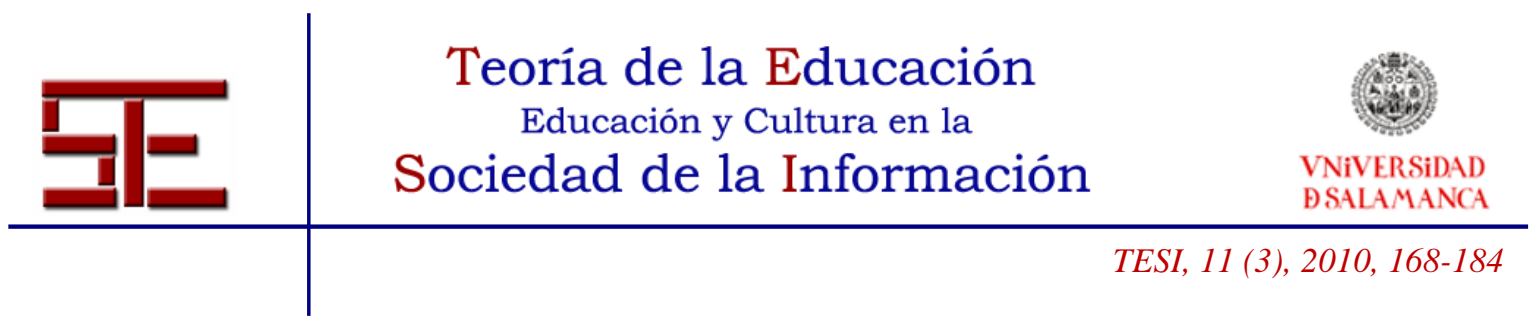

Desde nuestro punto de vista, dedicar un número de la revista a las mujeres es algo muy positivo; tratarlas de una manera diferente, algo muy negativo. No queremos decir que el autor de la editorial tenga que estar de acuerdo con este trato diferenciado, pero es muestra de que este comportamiento existe. El que los jugadores de rol corran a "proteger, mimar, contemplar y babear" a las jugadoras, no es el camino para que se produzca una verdadera integración de éstas en la afición. Y es que no es infrecuente que en las partidas de rol se lleguen a confundir personajes y jugadores, en tanto que el personaje de un jugador puede correr a proteger o a ayudar al de una jugadora por el hecho de que la jugadora sea mujer (algo que no tiene en absoluto nada que ver con el personaje). No es extraño, aunque sorprenda, ver cómo personajes de jugadores que en la realidad son pareja, acaben casándose en el mundo fantástico, aunque una sea una orgullosa y malvada elfa oscura, por ejemplo, y el otro un travieso gnomo.

Pese a ello, la situación en los últimos años ha cambiado de manera considerable.

La progresiva incorporación de las mujeres a los juegos de rol ha sido muy visible en las jornadas periódicas que se vienen desarrollando en nuestro país en los últimos años. Así, en los Encuentros Rúnicos que se celebran cada año en Rentería, posiblemente las jornadas con mayor asistencia femenina, se ha pasado del 10-15\% de chicas asistentes en los primeros años hasta casi un 40\% de chicas en el 2007.

En lo referente a las CLN, las Convivencias Lúdicas Nacionales, las jornadas de rol más importantes de nuestro país, el cambio ha sido también significativo. Así, en las CLN celebradas en Sestao en 1999, la ratio de las chicas no superaba el 2\%, mientras que en las CLN celebradas en Valladolid en 2006, el porcentaje de chicas rondaba el 30\%. Su actividad además fue muy visible en esas jornadas. En ellas se dio a conocer el Comando Gesserit, una asociación de jugadoras de rol, cuyo propósito es difundir los juegos de rol entre las mujeres. Su nombre hace referencia a la hermandad femenina de las Bene Gesserit de las novelas sobre Dune de Frank Herbert.

El decálogo de la asociación, que repartieron durante las jornadas, es muy significativo, y merece la pena leerlo aquí pues, aunque en clave de humor, apunta aspectos interesantes del tema que estamos tratando.

1. Nuestro propósito es animar a las frikis potenciales a reclamar su derecho a ser raras, y también ayudar a las veteranas a sentirse más integradas en este mundillo.

$2 .^{\circ}$ Esto no es un club de señoritas, así que los hombres estarán siempre invitados a participar.

3. ${ }^{\circ}$ Nuestros propósitos son lúdicos: lo que queremos es ijugar!

4. ${ }^{\circ}$ Si lo anterior no te ha quedado claro y piensas que somos unas feministas frikis castradoras... sencillamente, piérdete.

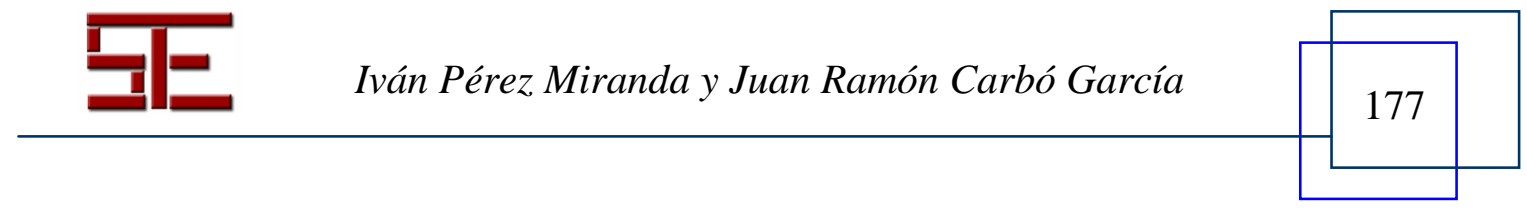




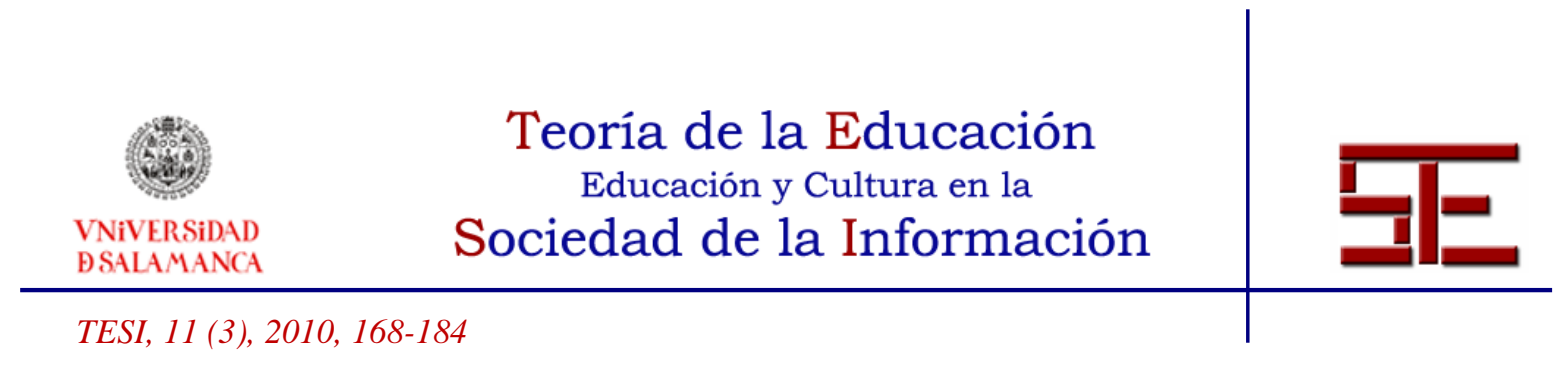

5. Nosotras somos diferentes pero jugamos a lo mismo que vosotros: no me des el papel de
dama en vez del de orco porque creas que soy demasiado sensible, no dejes de jugar a tu violento
videojuego por mí, no bajes tu espada de gomaespuma, ni creas que no puedo ver una peli
gore... Nosotras hacemos suflé y también TNT.
$6 .^{\circ}$ Ya sé que soy la única tía en la tienda/partida/jornadas/vivo pero no me siento halagada
cuando me miras ASÍ.
7. ${ }^{\circ}$ Sí a las camisetas frikis talla $S$, sí a la lencería de Star Trek, sí a los moldes de cocina con
formas cthulhuideas, sí a los bikinis ciberpunks: ¡sí al merchandising para chicas!
8..$^{\circ}$ Recorrer la ciudad buscando telas, medirse de los pies a la cabeza, coser complicados
adornos, pintar cartones y coser apliques... lo adoro. Nada en el mundo es mejor que disfrazarse.
9. ${ }^{\circ}$ Ya no somos las novias/hermanas/amigas-de. Cada vez somos más y mejor organizadas.
Queremos el poder y ahora tenemos un Comando para conseguirlo.
$10 .^{\circ}$ iQue empiecen los juegos!

El Comando Gesserit es un ejemplo de la incorporación activa de las mujeres a esta forma de ocio, una incorporación que tiene cada vez una visibilidad mayor, y que se muestra, a nuestro parecer, como uno de los pocos cambios positivos que ha tenido el mundo de los juegos de rol en los últimos años.

Hasta el momento, hemos expuesto someramente cómo se ha producido la incorporación de las mujeres al anteriormente masculino mundo de los juegos de rol, habiéndose convertido en jugadoras y directoras de juego.

Prestemos ahora atención a los personajes. Como decíamos anteriormente, lejos queda ya aquel tiempo en el que los juegos de rol consistían en explorar calabozos en busca de tesoros. Las ambientaciones posibles para un juego de rol son infinitas, exactamente las mismas que para una novela o una película. Las ambientación más clásica es la medieval-fantástica en todas sus variables desde los mundos de Espada y Brujería (como la Era Hyboria de Conan, o el mundo de Elric de Melniboné) a la Alta Fantasía (como El Señor de los Anillos, Dragonlance o Reinos Olvidados) pasando por los de fantasía oriental (como Leyenda de los 5 Anillos); muy populares son también los juegos de ciencia-ficción, desde los de Space Opera (como Star Wars o Star Trek), a los de ambientación ciberpunk (como Ciberpunk, o Muntant Chronicles). También encontramos juegos de rol basados en el terror, como los basados en las novelas de Lovecraft, Los mitos de Cthulhu, o los de terror gótico (Vampiro, Hombre Lobo, Momia, etc.). También existen los de ambientación histórica, como Aquelarre, ambientado en la Edad Media, o Comandos, ambientado en la Segunda Guerra Mundial. Todo es posible en un juego de rol, por lo que los personajes que se pueden crear son

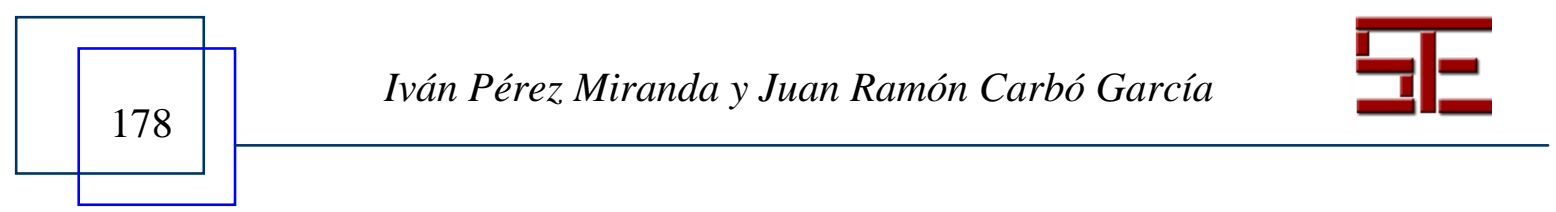




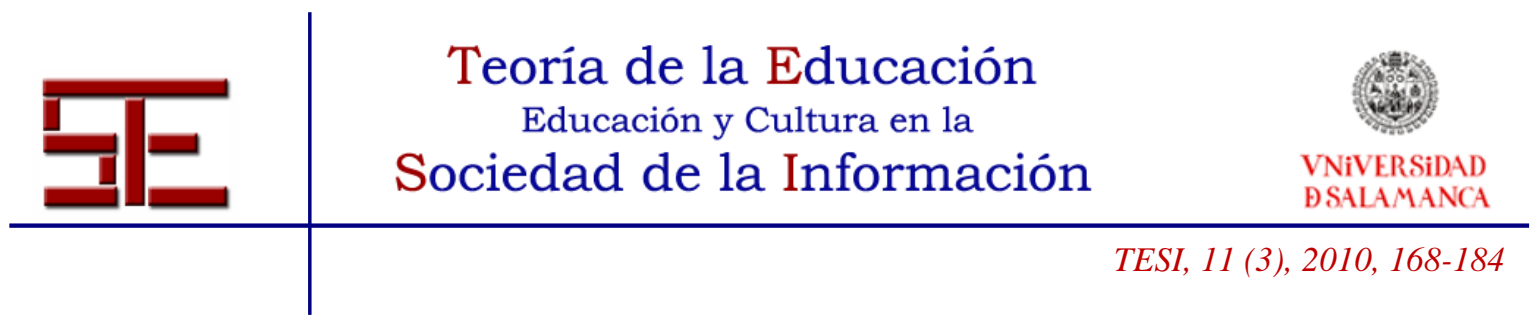

ilimitados. Desde el punto de vista de género es posible imaginar mundos donde el orden patriarcal es subvertido.

De este modo es posible imaginar una sociedad matriarcal, en su sentido más negativo, como la de los Elfos Oscuros de Menzoberranzan, en el mundo de Faerûn (Reinos Olvidados) donde las malvadas matronas gobiernan despiadadamente, y los elfos oscuros varones se hallan en una humillante situación de sometimiento. Es posible imaginar también mundos de fantasía donde no existe discriminación por razón sexo, y tanto los hombres como las mujeres pueden gobernar del mismo modo y ejercer las mismas profesiones. El juego de rol gratuito RyF (Rápido y Fácil) Héroes de Leyenda dedicaba un apartado al papel de las mujeres:

\footnotetext{
El papel de las mujeres en RyF, Heroes de Leyenda, es a su vez histórico y fantástico. Es decir, se puede tratar a las mujeres de forma que son madres y amas de casa, pero también grandes regentes poderosas casadas con hombres consortes.

Es más importante la condición de clase, el título, que el género de la persona.

Así una marquesa que se case con un lord, tendrá el control del feudo y su conyuge estará en un papel secundario. O no, dependiendo de lo que quiera hacer el narrador, pero, de facto, una mujer nunca será minusvalorada por los hombres.

Asímismo, una mujer puede ser una gran mercenaria, una magnífica general o una inquisidora suprema. No hay límite en cuanto a lo que una fémina puede hacer y lograr en este mundo. No hay prejuicios de sexo, ni de religión, ni en cualquier otro ámbito.

Eso no quita que en ciertas regiones, haya sociedades estrictamente masculinas, y en otras, estrictamente femeninas. Por ejemplo puede haber una Orden de Caballería de mujeres en la que se les prohíba tener ningún contacto sexual con un hombre.

Pero recuerda, una cosa son las excepciones, y otra la norma. Por norma, las mujeres y hombres tienen igualdad de oportunidades. (12):

<http://mercurio.homeip.net/ryf/index.php/Heroes_de_Leyenda:_El_papel_de_las_mujeres>
}

Los juegos de ciencia-ficción permiten también imaginar otras sociedades futuras en las que las diferencias de género se diluyan, acercándonos de este modo a planteamientos de autoras ciberfeministas como Donna Haraway (http://manifiestocyborg.blogspot.com/). También las Space Opera permiten fabular con sociedades menos desigualitarias. Ya en las primera película de la saga La Guerra de las Galaxias, de la que se han realizado varios juegos de rol, las mujeres asumen importantes puestos de poder en el bando rebelde, como es el caso de su líder Mon Mothma, o de la princesa Leia, quien "con su actitud firme, sus dotes de mando, unos valores rectos sin fisuras, concentrada en su carrera, y con su temor a comprometerse sentimentalmente, era una heroína propia de su tiempo" (Henderson, 2005, p. 159), sentando un precedente de héroe espacial femenino años antes de que las primeras

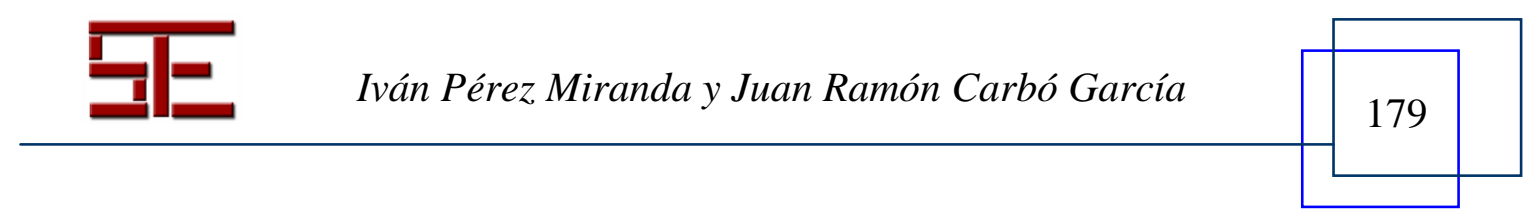




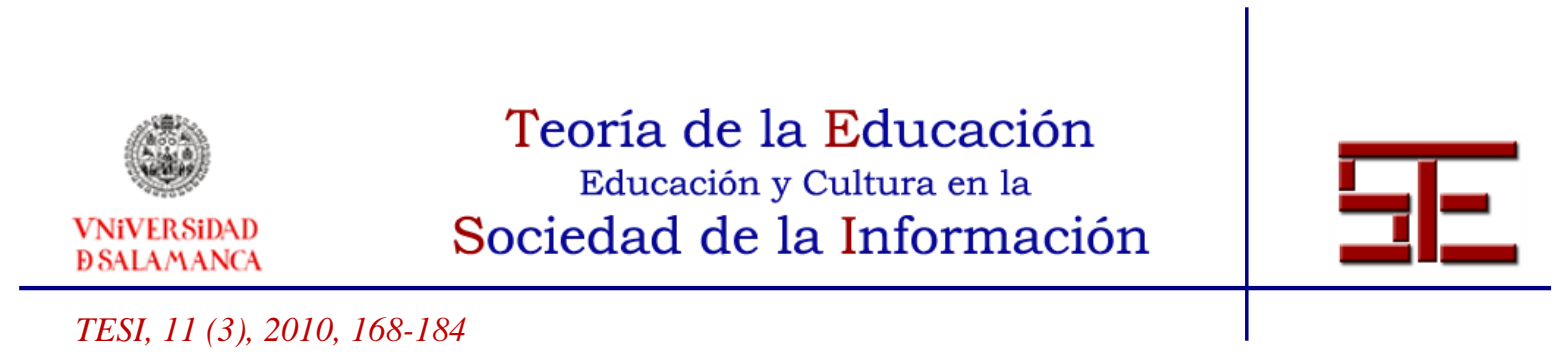

mujeres americanas pudieran salir al espacio (la soviética Valentina Tereshkova ya lo había hecho en 1963).

Otro género que presenta un gran interés dentro de los juegos de rol es, desde nuestro punto de vista, el de los juegos de rol de ambientación histórica, de innegable valor didáctico, que merecen un estudio aparte. En ellos se puede dar a conocer la situación de sumisión y de dependencia a la que han estado sometidas las mujeres durante milenios. Por supuesto que se pueden interpretar personajes que se resistan, que se salgan de la norma. Nada impide interpretar, por ejemplo, el arquetipo de doncella guerrera como Juana de Arco o como Catalina de Erauso, la monja Alférez, pero evidentemente el personaje se verá enfrentado a serias dificultades por su sexo, lo que le hará mucho más interesante la trama. Ante este hecho, las reglas de juego pueden favorecer a los personajes femeninos para compensar la dificultad interpretativa añadida, o bien perjudicarlas para limitar el número de personajes excepcionales, si bien un personaje interpretado por un jugador es, por definición, un personaje excepcional, protagonista de la historia que se narra.

El juego de rol de El Capitán Alatriste, escrito por Ricard Ibáñez y publicado por Devir Iberia (2002), opta por poner trabas a los personajes femeninos que se salgan de la norma socialmente establecida en el Siglo de Oro, de este modo se nos dice lo siguiente:

\begin{abstract}
El juego de rol del capitán Alatriste pretende ser un juego más o menos histórico. Eso quiere decir que no se van a ver en él a mujeres con botas terciadas y toledana en mano buscando jarana por las calles de Madrid. Si quieres eso, te has equivocado de juego... De los doce tipos de personaje, cuatro pueden ser llevados por mujeres sin problemas (clérigo [monja], cortesana, cómica y pícara) y dos están pensados exclusivamente para ellas (dueña y tapada). Para jugar los otros, un PJ femenino ha de tener la ventaja de Aliados y crear un seguidor masculino que sea su protector en este mundo de "machos"...

A no ser que prefiera el recurso de hacerse pasar por hombre. Ejemplos no faltan, tanto históricos (Catalina de Erauso, la "Monja Alférez") como ficticios. El teatro de la época usa ese recurso numerosas veces: en las tablas es frecuente ver cómo personajes femeninos se disfrazan de hidalgos (Don Gil de las Calzas Verdes, El anzuelo de Fenisa, Los bandos de Sena), soldados (La serrana del Tormes), aldeanos (El molino), criados (El lacayo fingido). Hasta el conde de Villamedina gustaba de hacerse acompañar, en sus correrías nocturnas por mandrachos y mancebías, por la hija de unos labriegos de sus pagos convenientemente disfrazada de paje... Sin embargo, que sea posible no quiere decir que lo tengan fácil. ( 34-35).
\end{abstract}

No menos interesante es el apartado referido a "las armas y las mujeres":

Aunque algunas mujeres llegaron a aprender esgrima e incluso a practicar duelos unas contra otras, estaba absolutamente prohibido que una mujer llevara espada y aún más que supiese

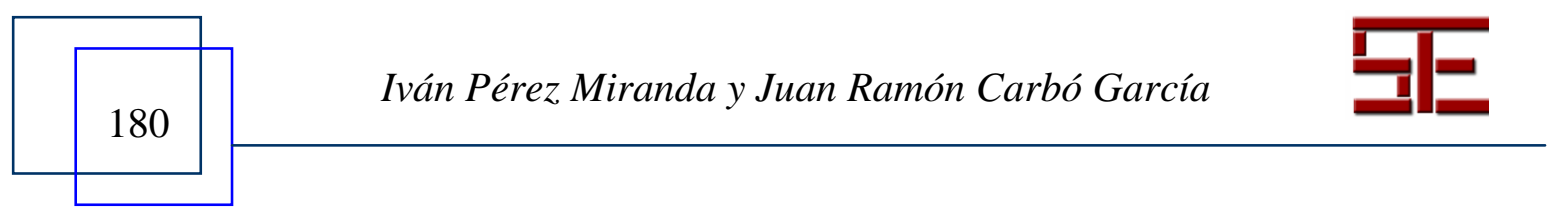




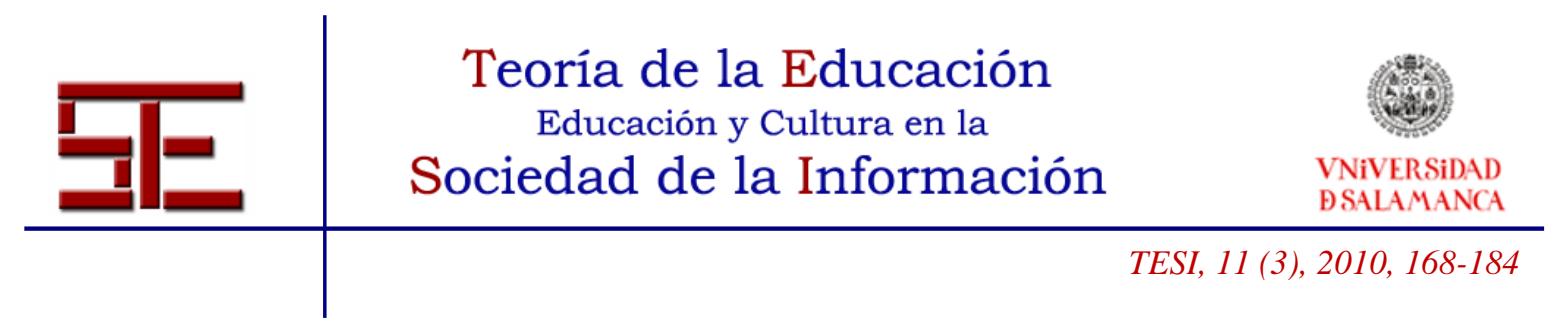

manejarla. La espada era el símbolo máximo de la nobleza, y que un ser claramente inferior (con perdón) la manejase era tenido como gran escándalo y afrenta. Casos como el de la Monja Alférez, en los que una mujer con un par de ovarios resultó ser más hombre que cualquier hombre (y más mujer que cualquier mujer) se dieron, pero fueron muy, muy raros. Para reflejar esto en el juego, si un personaje femenino desea aprender Esgrima inicialmente, no podrá aprender la habilidad a un nivel superior a su CD-1, tendrá 3 puntos para comprar maniobras en lugar de 6 y cada punto de Clases de esgrima le costará 10 PX en lugar de 5. Esto no se aplica a las armas de fuego. Debido a la inseguridad reinante en calles y caminos, se puso de moda en la época que las mujeres nobles llevaran pequeñas pistolas (pistoletes), muchas de ellas adornadas con engastes de metales preciosos. La condesa de Monterrey, pariente del conde-duque de Olivares, se hizo retratar con un pistolete al cinto... y al parecer lo solía llevar como cosa habitual. Aunque muchas los llevaban como moda y adorno, no era en absoluto la norma: sin ir más lejos, la marquesa de Leganés mató de un tiro al cochero del almirante de Castilla cuando éste se negó a cederle el paso en una calle estrecha. Evidentemente, los personajes femeninos tienen absolutamente prohibido aprender cualquier otro tipo de armas (asta, pesadas, etc.); excepción hecha de las armas cortas (dagas o similar), con las que tienen un coste de aprendizaje igual a los hombres. (74-75).

Aunque se trate de unas reglas de juego que puedan ser cuestionadas, lo que sí es cierto es que los jugadores, a través de la inmersión en el juego, pueden obtener un mayor conocimiento de la época histórica en que se ambienta, y sobre las relaciones de género que en ella tenían lugar. El conocimiento crítico del pasado es fundamental para comprender nuestro presente y poder construir un futuro más justo, y los juegos de rol pueden constituir una herramienta formidable para la enseñanza de la historia, de un modo semejante a cómo puede suceder, por ejemplo, con la novela histórica.

Por otra parte, la experiencia de interpretar personajes de distinto sexo, aunque entraña cierta dificultad, puede ser muy interesante y positiva, y puede permitir reforzar los sentimientos de empatía, al poder entrar en la piel de "el otro". Podemos, a través de ellos, comprender mejor cómo se crean las identidades y las alteridades, y sin duda ofrece un enorme potencial para la coeducación. Véase por ejemplo el uso educativo que se hace desde los juegos de rol desde Educarueca: http://www.educarueca.org/spip.php?rubrique29

Los juegos de rol, muy lejos de ser la panacea, pueden ser utilizados con fines educativos permitiendo transmitir, no sólo una serie de conocimientos, sino también de actitudes. Refuerzan de manera notable el interés por otras formas de cultura como la literatura, el cine, los cómics, e incluso la música, lo que desarrolla considerablemente la imaginación de los jugadores, así como sus habilidades comunicativas. Sea como sea, la imaginación, con todo el peligro que puede suponer para quienes ostentan el poder, es

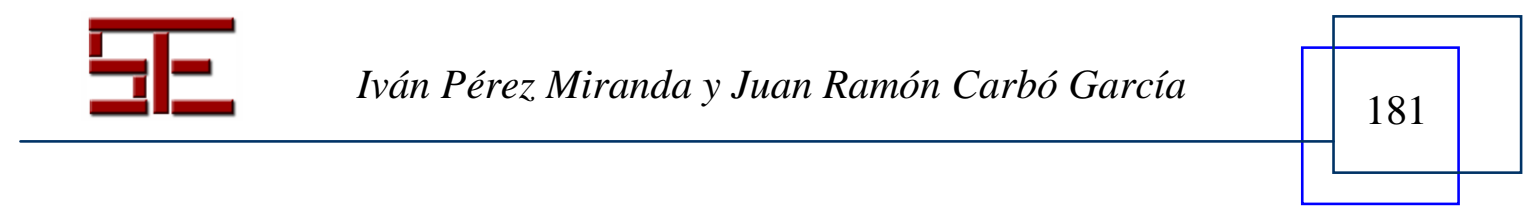




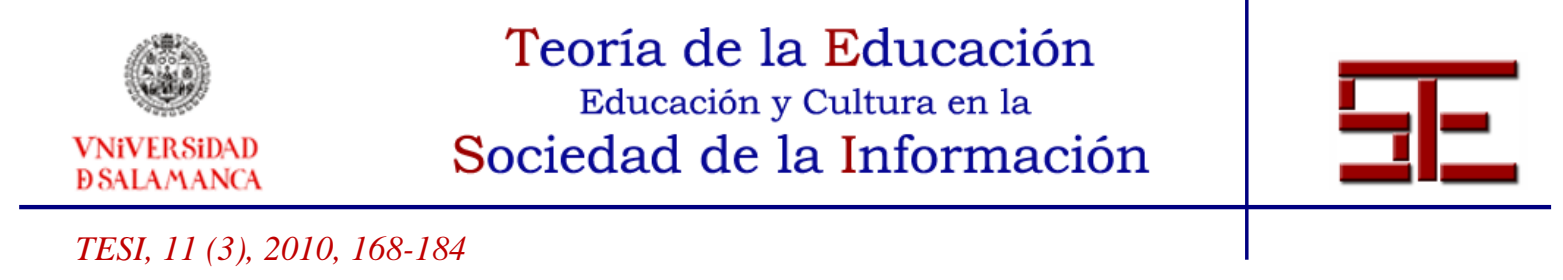

una herramienta fundamental si queremos construir un futuro más justo y equitativo. Es por ello por lo que proponemos que los educadores (maestros, profesores, padres, etc.) no se desentiendan de los juegos no infantiles, como son los propios juegos de rol u otros como los juegos estrategia o los videojuegos por ejemplo, que dejen de verlos como algo curioso, raro, o peligroso y se fomente su uso de una manera responsable.

\section{BIBLIOGRAFÍA.}

Fernández, J. (1988). Desarrollo de la doble realidad del sexo y del género. Madrid: Pirámide.

Fraise, G. (2003). El concepto filosófico de género, en TUBERT, S. (ed.), Del sexo al género. Madrid: ediciones Cátedra, 39-46.

García Mouton, P. (2002). "Género" como traducción de gender, ¿anglicismo incómodo?. En Vigarata Tauste, A.Mª ; Jiménez Catalán, R. Mª (eds.), "Género”, sexo, discurso. Madrid: Ediciones del laberinto.

Henderson, M (2005). Star Wars. La magia de un mito. Barcelona: Círculo Latino.

Leppälahti, M. (2003). Gender play? Playing man and woman in role-playin games,En: $<$ http://www.iiav.nl/epublications//2003/Gender_and_power/5thfeminist/paper_554.pdf

Revista Nosolorol. ( 2005, marzo). Mujer y Friki, esa extraña especie (editorial), $\mathrm{n}^{\mathrm{o}} 22$, En <http://www.nosolorol.com/revista/index.php?nrev=22\&nsec=1>

San Sebastián, I (2009). Machismo en píldoras, [Versión electrónica]. El Mundo, 14 de mayo de 2009.

http://www.elmundo.es/opinion/columnas/isabel-san-sebastian/2009/05/14836885.html

San Sebastian Cabasés, I; San Sebastian Cabasés, J (2004), ¿A qué juegan nuestros hijos?: botellón, rol, videojuegos y otros peligros de la infancia y la adolescencia. Madrid: La Esfera de Libros.

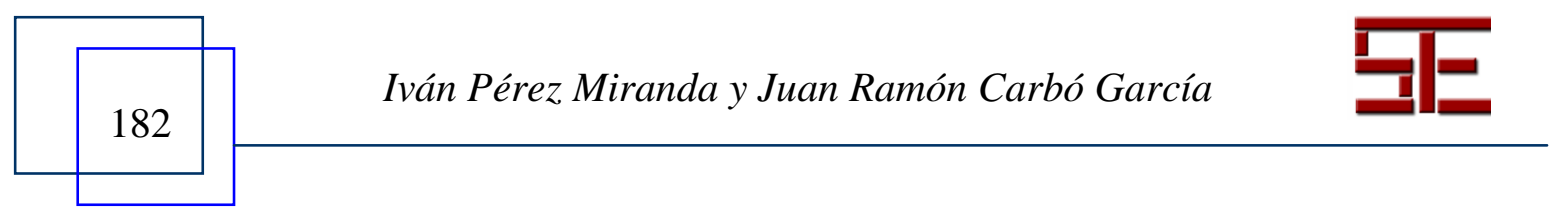




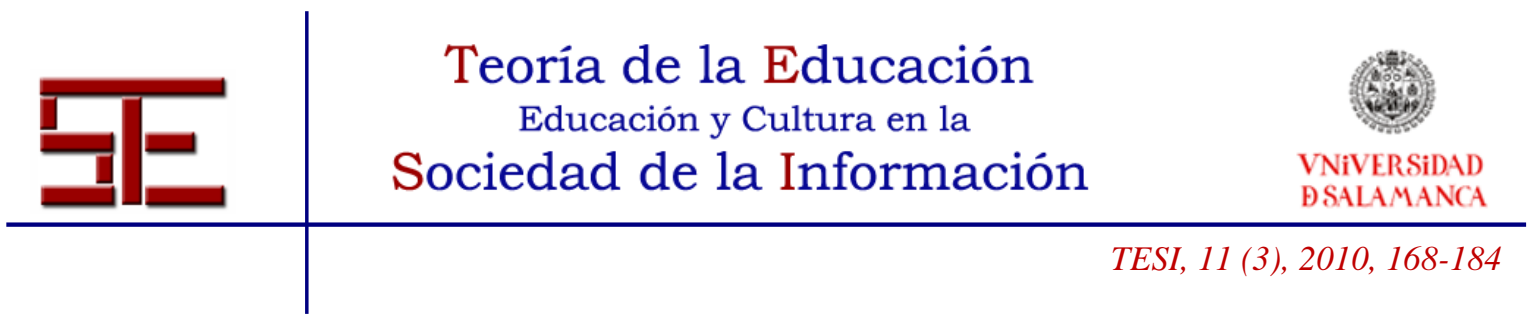

Sanahuja Yll, Ma E. (2005). ¿Género o Mujeres, en Sevillano San José, M ${ }^{\mathrm{a}}$.C.; Rodríguez Cortés, J.; Olarte Martínez, M.; Lahiz, L. (eds.). El Conocimiento del Pasado. Una herramienta para la igualdad. (pp.87-92). Salamanca: Plaza Universitaria Ediciones.

Sánchez, D. (2007). Juegos de Rol: Mito y Realidad. Trabajo de investigación. Disponible electrónicamente en:

<http://dreamers.com/defensadelrol/articulos/Juegos_de_rol__Mito_y_realidad.pdf>

Sau, V. (2000). Diccionario ideológico feminista, I. Barcelona: Icaria.

Sevillano Pareja, H (2008). El sector editorial de los juegos de Rol: análisis del editor, el lector y el traductor. Tesis doctoral. Universidad de Salamanca.

Tizón, R (2007): Creer lo Increíble. Madrid: NoSoloRol.

Torres, R,(2004). Una necrosis similar, [Versión electrónica]. El Mundo, 9 de junio. http://www.elmundo.es/papel/hemeroteca/1994/06/09/television/718612.html>

\section{ENLACES DE INTERÉS}

Juegos de rol y simulación en Educaruca:

$<$ http://www.educarueca.org/spip.php?rubrique29>

RPG Theory.

<http://www.darkshire.net/ jhkim/rpg/theory/>

Links for Gender Issues and Role-playing.

<http://www.darkshire.net/ jhkim/rpg/theory/gender/links.html>

Web para la defensa de los juegos de rol.

<http://dreamers.com/defensadelrol/articulos.htm>

Articles de jeuderôlogie. Fabien Niñoles.

<http://harmonies.tzone.org/articles/jeuderologie/jeuderologie.pdf >

The Christian Gamers' Guild.

<http://www.christian-gamers-guild.org/wtd.html>

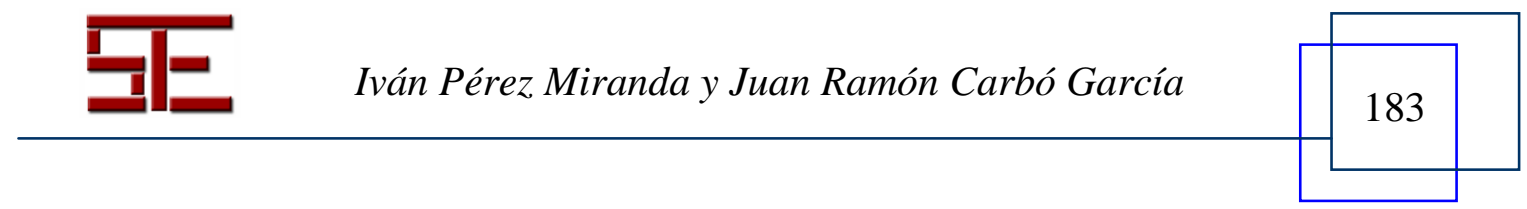




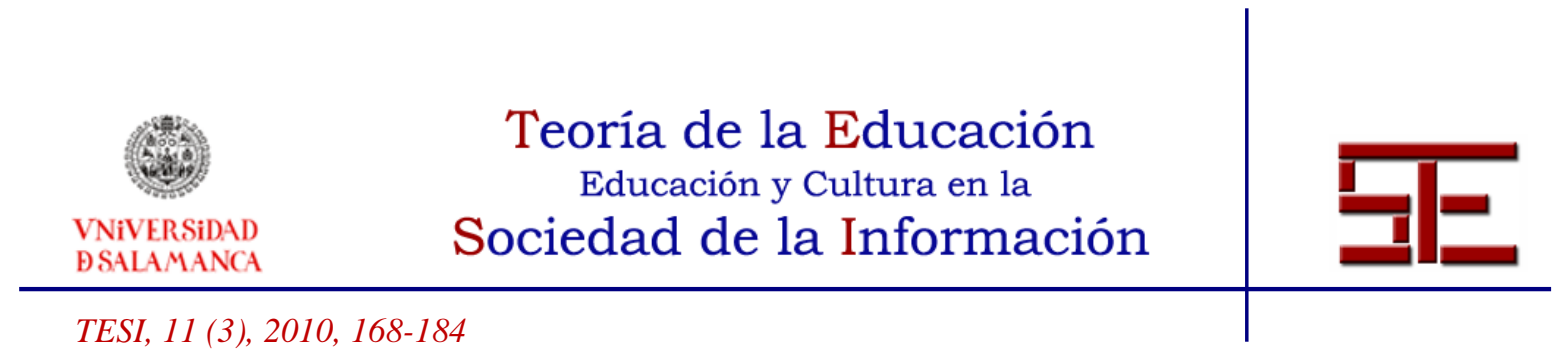

Role, Play, Art. Collected Experiences of Role-Playing.

$<$ http://jeepen.org/kpbook/kp-book-2006.pdf>

As LARP Grows Up - The Book from Knudepunkt 2003.

$<$ http://www.laivforum.dk/kp03_book/>

International Journal of Role-Playing.

$<$ http://journalofroleplaying.org/>

Rol para peques.

$<$ http://rolparapeques.rolgratis.com/>

Juegos de rol gratuitos.

$<$ http://www.rolgratis.com/>

Interactive drama.

<http://www.rpg.net/larp/index.html>

Para citar el presente artículo puede utilizar la siguiente referencia:

Carbó García, J.R. y Pérez Miranda, I. (2010): Juegos de rol y roles de género, en Orejudo González, J.P. (Coord.) Perspectiva educativa y cultural de "juego de rol". Revista Teoría de la Educación: Educación y Cultura en la Sociedad de la Información. Vol. 11, no 3. Universidad de Salamanca, pp. 168-184 [Fecha de consulta: dd/mm/aaaa]. http://campus.usal.es/ revistas_trabajo/index.php/revistatesi/article/view/7456/7472 